\title{
Research on Evaluation System of University's Talent Competitiveness_-A Case Study of 211 Colleges and Universities in Jiangsu Province
}

\author{
Lei Zhu', a, Xiaoxiao Kong ${ }^{2, b,{ }^{*}}$ \\ ${ }^{1}$ School of Economics and Management, Nanjing University of Science and Technology, China \\ ${ }^{2}$ School of Economics and Management, Nanjing University of Science and Technology, China \\ a1103204132@qq.com, b563041472@qq.com
}

*Corresponding author: Lei Zhu, Master, 1103204132@qq.com

Keywords: Talent competitiveness; Evaluation index system; Influencing factors; Factor analysis

\begin{abstract}
To realize the strategy of building a strong country in colleges and universities, it is necessary to improve the competitiveness of university personnel. A reasonable and effective evaluation of the talent competitiveness of colleges and universities is an important basis for measuring talents' work. Based on the assessment of the talent competitiveness of universities at home and abroad and related research, this article takes the 211 colleges and universities in Jiangsu Province as an example to carry out empirical research. Combining with the actual situation of talents in colleges and universities, it mainly includes the scale of talents in universities, the quality of talents, the construction of talents platform, and talents. Contributions to science and technology and five other aspects of the construction of university talent competitiveness evaluation index system, and collected 211 colleges and universities in Jiangsu Province in 2012-2016 data, the use of factor analysis method of Jiangsu Province, 211 colleges and universities in the overall situation of talent competitiveness The analysis and talent competitiveness of 211 colleges and universities in Jiangsu Province were ranked.
\end{abstract}

\section{Introduction1 Overview of Talent Competitiveness in Colleges and Universities}

With the development of the knowledge economy and globalization, Chinese universities are faced with enormous competition in terms of students, funds, and talents. The strategy for building a strong country in higher education has been included in the Outline of the National Medium- and Long-Term Education Reform and Development Plan (2010-2020). Higher education competitiveness is the core and foundation of national competitiveness [1]. Constructing a strong province of higher education is an important part of the strategy to build a stronger country in higher education. To achieve economic and social development in Jiangsu Province, "two are the first", we must first complete the strategy of rejuvenating the province through science and education and strengthening the province. Human resources are the first resources for the development of college education. The competition among universities is ultimately the competition of talents. The advantage in competition depends on the advantages of talents.

Based on the theory of strategic management, this paper puts forward the evaluation index system of talents competitiveness in universities and colleges in Jiangsu Province on the premise of summarizing the research results of the scholars. It uses statistical software methods such as spss to analyze it, and further evaluates the talents of Jiangsu 211 universities based on the evaluation results. Competitive rankings.

\section{Overview of Talent Competitiveness in Colleges and Universities}

The concept of "core competence" was first proposed for enterprises, and it is believed that the company's core competitiveness comes from the company's cumulative knowledge, and the final result is represented by core products or services. In recent years, some scholars have begun to pay 
attention to applying the concept of core competitiveness to the development of higher education. Liu Xiangbing proposes that the university's core competencies are the talent cultivation capabilities and academic research capabilities of universities. Cultural factors, disciplinary resources, human resources, material resources, and intangible resources are the support for the formation of competitiveness [2]. Shen Jian believes that the key to the strategy of strengthening the province's higher education is to establish the concept of core competitiveness, build a platform for innovation of superior disciplines, improve scientific research and innovation capacity of universities, optimize the structure of higher education, and build a high-quality teacher team [3].

Human resources in colleges and universities are regarded as strategic resources for the development of higher education and have always been the focus of attention in higher education institutions and human resource management circles. Weng Guangcong conducted a theoretical analysis of the incentive mechanism of college teachers [4]; Zeng Weiming et al. emphasized that teachers' competency should be reformed from the aspects of selecting, employing, educating, and retaining people in colleges and universities [5]. The second is the quantitative analysis is less and only for a certain part or part of the human resources management in colleges and universities. Li Feng and others used data mining methods to provide strategies for the introduction and cultivation of talents in colleges and universities, and provided a quantitative analysis solution to solve the problem of human resource management[6].

A competitive university is no longer confined to traditional teaching, but also shoulders the responsibility of scientific research innovation and social services. How to use effective and effective human resources management methods to manage and build a high-quality teaching staff should become a concern of current universities. Hot spots and focus.

\section{Construction of Evaluation Index System for Talent Competitiveness in Colleges and Universities}

\subsection{Evaluation Index System Design Principles}

Statistical indicator system refers to the organic whole made up of several interconnected statistical indicators. A statistical indicator reflects social and economic phenomena from only one aspect, while social and economic phenomena are multifaceted and complex. To comprehensively and systematically reflect socio-economic phenomena, it is necessary to establish an objective, systematic, and effective evaluation system that must be clear. Design principles, and based on the principles to determine the content of indicators and the relationship between indicators [7]. The assessment of talents' competitiveness in colleges and universities is a complex systematic project. The evaluation process must embody the principle of combining static evaluation with dynamic evaluation. It needs to adopt multiple indexes comprehensive evaluation method to evaluate. The design of talent competitiveness evaluation system in colleges and universities needs to follow the principles of science, system, feasibility and comparability.

\subsection{Evaluation Index System of Talent Competitiveness in Colleges and Universities}

The level of human resources competitiveness in colleges and universities is affected by the size of talents, the quality of talents, the construction of talent platforms, the educational contribution of talents, and the contribution of science and technology. Based on relevant research literature, combining with the actual situation of universities in Jiangsu Province, an evaluation index system for talents competitiveness in universities is established. The quality of talent includes the introduction of high-end talents and the cultivation of high-end talents; the construction of a talent platform includes innovation platforms and results transformation entrepreneurship platforms; Cultivate students and innovative educational achievements; talent and technology contributions include vertical and horizontal topics. Finally, five first-level indicators, nine second-level indicators and 18 third-level indicators were evaluated. The results are shown in Table 3-1. 
Table 3-1. Evaluation Index System of Talent Competitiveness in Colleges and Universities

\begin{tabular}{|c|c|c|c|}
\hline $\begin{array}{l}\text { First-level } \\
\text { indicators }\end{array}$ & Secondary indicators & Third-level indicators & Symbol \\
\hline \multirow[t]{3}{*}{ Talent scale } & \multirow{3}{*}{ Talent scale } & Total number of full-time teachers & A1 \\
\hline & & Number of full-time teachers with positive senior titles & $\mathrm{A} 2$ \\
\hline & & Number of full-time teachers with doctoral degrees & A3 \\
\hline \multirow[t]{5}{*}{ Talent quality } & Introduce high-end talent & Thousands of people plan candidates & B1 \\
\hline & \multirow{4}{*}{ Cultivate high-end talent } & Cheung Kong Scholar Distinguished Professor & $\mathrm{B} 2$ \\
\hline & & Ten thousand plan & B3 \\
\hline & & National Green Youth & B4 \\
\hline & & National Youth & B5 \\
\hline \multirow[t]{2}{*}{ Talent platform } & Innovation platform & National Key Laboratory & $\mathrm{C} 1$ \\
\hline & $\begin{array}{l}\text { Achievements transformation } \\
\text { entrepreneurship platform }\end{array}$ & Corporate Graduate Workstation & $\mathrm{C} 2$ \\
\hline \multirow{4}{*}{$\begin{array}{l}\text { Contribution to } \\
\text { talent education }\end{array}$} & \multirow{3}{*}{ Train students } & The total number of graduate students in the year & D1 \\
\hline & & $\begin{array}{c}\text { Total number of full-time foreign students studying abroad at the time of } \\
\text { graduation }\end{array}$ & D2 \\
\hline & & $\begin{array}{l}\text { Graduates' initial employment rate } \\
\end{array}$ & D3 \\
\hline & $\begin{array}{c}\text { Innovative educational } \\
\text { achievements }\end{array}$ & Nearly five years & D4 \\
\hline \multirow{4}{*}{$\begin{array}{c}\text { Talent } \\
\text { Technology } \\
\text { Contribution }\end{array}$} & \multirow{3}{*}{ Longitudinal issues } & Nearly five years of research funding & E1 \\
\hline & & $\begin{array}{l}\begin{array}{l}\text { Number of Major Projects of National Social Science Funds led by the past five } \\
\text { years }\end{array} \\
\end{array}$ & E2 \\
\hline & & $\begin{array}{l}\text { The number of major projects of provincial social sciences fund led by the past } \\
\text { five years }\end{array}$ & E3 \\
\hline & Horizontal topics & Nearly five years of horizontal research funding & E4 \\
\hline
\end{tabular}

\section{Empirical analysis and results}

\subsection{Samples and Data Sources}

The purpose of this paper is to study the level of talent competitiveness and its influencing factors in colleges and universities in Jiangsu Province Taking into account the feasibility and accuracy of data acquisition and the degree of data differences between universities, this paper selected data from 211 universities in Jiangsu Province in 2012-2016. The sample data were compiled and calculated from the statistical data provided by the Jiangsu Talents Competitiveness Report and Statistical Yearbook of Jiangsu Province. The data was comprehensive, scientific, reliable and accurate.

\subsection{Computational Analysis of Talent Competitiveness in Colleges and Universities}

This paper uses the factor analysis method to deal with the tertiary indicators of colleges and universities personnel competitiveness, so as to obtain the public factor. Twenty primary statistical indicators were analyzed by principal component analysis using exploratory factors. The results revealed three common factors. These three public factors extracted $85.445 \%$ of total variance variance (Table 4-1). According to the structure of the rotated factor load matrix, F1 was named as the talent quality factor for college talents' competitiveness, F2 was named as the talent scale factor for college talents' competitiveness, and F3 was named as the talent contribution factor for college talents' competitiveness.

Table 4-1. Evaluation Index System of Talent Competitiveness in Colleges and Universities

\begin{tabular}{|c|c|c|c|c|c|c|c|c|c|}
\hline \multirow{2}{*}{ Component } & \multicolumn{3}{|c|}{ Initial Eigenvalues } & \multicolumn{3}{c|}{ Extract Sums of Squared Loadings } & \multicolumn{3}{c|}{ Rotation Sums of Squared and loadings } \\
\cline { 2 - 11 } & Total & \% of Variance & Cumulative \% & Total & \% of Variance & Cumulative \% & Total & \% of Variance & Cumulative \% \\
\hline 1 & 11.981 & 59.904 & 59.904 & 11.981 & 59.904 & 59.904 & 9.402 & 47.008 & 47.008 \\
2 & 3.093 & 15.467 & 75.371 & 3.093 & 15.467 & 75.371 & 5.516 & 27.578 & 74.586 \\
3 & 2.015 & 10.074 & 85.445 & 2.015 & 10.074 & 85.445 & 2.172 & 10.860 & 85.445 \\
\hline
\end{tabular}

According to the rotated factor loading matrix coefficient, the expressions of F1, F2, F3, and F4 can be obtained: $\mathrm{F} 1=0.196 \mathrm{~A} 1+0.510 \mathrm{~A} 2+0.434 \mathrm{~A} 3+0.937 \mathrm{~B} 1+0.977 \mathrm{~B} 2+0.192 \mathrm{~B} 3+0.850 \mathrm{~B} 4+0.990 \mathrm{~B} 5-0.09$ $9 \mathrm{C} 2+0.711 \mathrm{D} 1+0.663 \mathrm{D} 2+0.334 \mathrm{D} 3+0.935 \mathrm{D} 4+0.673 \mathrm{E} 1+0.929 \mathrm{E} 2+0.358 \mathrm{E} 3+0.202 \mathrm{E} 4 ; \mathrm{F} 2=0.885 \mathrm{~A} 1+0$ $.800 \mathrm{~A} 2+0.856 \mathrm{~A} 3+0.265 \mathrm{~B} 1+0.141 \mathrm{~B} 2+0.322 \mathrm{~B} 3+0.376 \mathrm{~B} 4+0.090 \mathrm{~B} 5+0.902 \mathrm{C} 2+0.604 \mathrm{D} 1+0.508 \mathrm{D} 2-0$. 
$064 \mathrm{D} 3+0.015 \mathrm{D} 4+0.487 \mathrm{E} 1+0.316 \mathrm{E} 2+0.207 \mathrm{E} 3+0.885 \mathrm{E} 4 ; \mathrm{F} 3=-0.274 \mathrm{~A} 1-0.254 \mathrm{~A} 2-0.086 \mathrm{~A} 3-0.033 \mathrm{~B} 1+$ $.071 \mathrm{~B} 2+0.602 \mathrm{~B} 3+0.126 \mathrm{C} 2-0.210 \mathrm{D} 1-0.503 \mathrm{D} 2+0.759 \mathrm{D} 3+0.304 \mathrm{D} 4+0.202 \mathrm{E} 1-0.090 \mathrm{E} 2-0.693 \mathrm{E} 3$;

The eigenvalue contribution rate is weighted, and the comprehensive factor score calculation formula is: $\mathrm{F}=0.47008 \mathrm{~F} 1+0.27578 \mathrm{~F} 2+0.10860 \mathrm{~F} 3$. By calculating the scores and ranking of comprehensive factors for each sample, the talent competitiveness of 211 colleges and universities in Jiangsu is shown in Table 4-2.

Table 4-2. Ranking of Talent Competitiveness of 211 Colleges and Universities in Jiangsu Province

\begin{tabular}{|c|c|c|c|c|c|c|c|c|}
\hline SCHOOL & $\begin{array}{l}\text { Overall } \\
\text { ratings }\end{array}$ & Rank & $\begin{array}{c}\text { Talent Quality } \\
\text { Factor Score }\end{array}$ & $\begin{array}{c}\text { Ran } \\
\mathrm{k}\end{array}$ & $\begin{array}{l}\text { Talent scale } \\
\text { factor score }\end{array}$ & $\begin{array}{c}\text { Ran } \\
\mathrm{k}\end{array}$ & $\begin{array}{l}\text { Talent Contribution } \\
\text { Factor Score }\end{array}$ & $\begin{array}{c}\text { Ran } \\
k\end{array}$ \\
\hline Nanjing University & 1.25 & 1 & 2.89969 & 1 & -0.38393 & 7 & -0.07938 & 8 \\
\hline Southeast University & 0.86 & 2 & 0.41214 & 2 & 1.97806 & 1 & 1.09915 & 1 \\
\hline Suzhou University & 0.07 & 3 & -0.29786 & 5 & 1.3925 & 2 & -1.56481 & 10 \\
\hline $\begin{array}{c}\text { Nanjing University of Science and } \\
\text { Technology }\end{array}$ & -0.12 & 4 & -0.39082 & 8 & 0.05415 & 4 & 0.46064 & 6 \\
\hline Nanjing University of Aeronautics & -0.16 & 5 & -0.53923 & 10 & 0.39158 & 3 & -0.1643 & 9 \\
\hline Jiangnan University & -0.19 & 6 & -0.5639 & 11 & -0.01919 & 6 & 0.77897 & 2 \\
\hline He Hai University & -0.19 & 7 & -0.51492 & 9 & 0.0028 & 5 & 0.4865 & 5 \\
\hline Nanjing Agricultural College & -0.19 & 8 & -0.07921 & 3 & -0.59775 & 10 & 0.12338 & 7 \\
\hline China University of Mining & -0.28 & 9 & -0.38305 & 7 & -0.55151 & 8 & 0.51193 & 4 \\
\hline Nanjing Normal University & -0.5 & 10 & -0.21551 & 4 & -0.57938 & 9 & -2.16997 & 11 \\
\hline China Pharmaceutical University & -0.56 & 11 & -0.32731 & 6 & -1.68732 & 11 & 0.51788 & 3 \\
\hline
\end{tabular}

\subsection{Evaluation of results}

Nanjing University, Southeast University, Suzhou University, Nanjing University of Science and Technology, and Nanjing University of Aeronautics and Astronautics ranked among the top five universities in terms of comprehensive talent competitiveness. Among the talent quality factor scores, Nanjing University, Southeast University, Nanjing Agricultural University, Nanjing Normal University The universities and Soochow University are among the top five; among the talent scale factor scores, Southeast University, Suzhou University, Nanjing University of Aeronautics and Astronautics, Nanjing University of Technology and Hohai University are among the top five; in the talent contribution factor score, Southeast University, Jiangnan Universities, China Pharmaceutical University, China University of Mining and Hohai University are among the top five.

\section{References}

[1] Zhou Yuanqing. Pay attention to educational scientific research and build a strong country of higher education [J]. China Higher Education Research, 2010 (12): 1 -5.

[2] Liu Xiangbing. Discriminating factors of university core competitiveness [J]. Journal of Renmin University of China, 2007 (2): 143 -148.

[3] Shen Jian. The concept and practice of building a strong province of higher education [J]. Jiangsu Higher Education, 2011(1): 1 -4 .

[4] Weng Guangcong. Research on the Incentive Mechanism of University Teachers [J]. Science and Technology Management Research, 2010 (14): 119-122;

[5] Zeng Weiming, Xiao Yao, An Peiwang. Competency-based Human Resource Management in Universities [J]. Heilongjiang Higher Education Research, 2010 (8): 42 -44

[6] Li Feng, Yin Jie, Wu Jie. Research on talents introduction and training strategy based on data mining in colleges and universities [J]. Science and Technology Progress and Countermeasures, 2010, 27 (12): $149-151$

[7] Schuler R S, Susan S E, Jackson Tarique I. Global talent man-mentment and global talent challenges: Strategic opportunities for IHRM[J]. Journal of World Business, 2010, (10): 461-472 